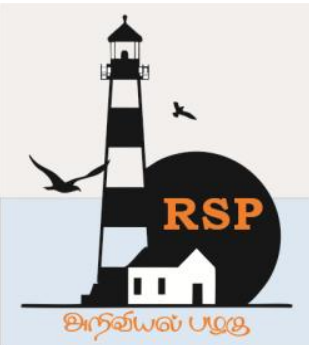

INTERNATIONAL RESEARCH JOURNAL ON ADVANCED SCIENCE HUB

\title{
Analysis of Oxygen Utilization and Its Effects
}

\author{
Shaziya Mohammed Irfan Momin
}

Assistant Professor, Department of Chemistry, G.M.Momin Women's College, Bhiwandi, Dist Thane, Maharashtra, India

\begin{abstract}
The present investigation is carried out using lake water from Bhiwandi city. Most of the biological organisms, micro-organisms present in the water require oxygen for their survival and growth. They utilize the oxygen present in the water. The biological processes decompose oxygen present in the water which may result in decrease in the level of oxygen to such extent which is necessary for normal growth of other aqua fauna. It is found that decline in dissolved oxygen concentration is one of the most important factor that directly affect the lifecycle of most of the aquatic animals. The results of oxygen utilized by the biological process which may not necessary for aquatic ecosystem, are then compared with the standard values prescribed by the standard bodies.
\end{abstract}

Keywords: Bhiwandi City, Oxygen Utilization, Lake Water.

\section{Introduction}

In a current scenario pollution is a hot topic as everybody is affected by polluted things may be eatables or non eatables. As good health is necessary for happy and pleasant life. This a small scale research work which is carried out to find the level of oxygen utilized by micro organisms which are present in the water body and how does this utilized oxygen get reduced in the water reservoir which is required for some metabolic process in aquatic animal and also for maintenance of good quality water, as most of the undesired biological organism contaminate and pollute water and make the water very hazardous and harmful which are not required at all, so in this paper it is estimated that how much amount of oxygen get utilized by such organisms which may produce due to long term remains of the various materials which are used in decoration of Idols. The lake under study Varal Devi Lake.Major activity of the people living near this lake is fishing and this fish is used as food. Lake Varal Devi is important and attractive place for tourists and this lake gives a very pleasant atmosphere. This lake water form the habitate for most of the flora and fauna by maintaining the ecological system. The local fisher man capture the fish from the lake and use it in their daily diet and they do marketing of fish also.The present research work aims to estimate the level of Biological Oxygen Demand in the Varal Devi lake (5). Anant Chaturti is thefinale and culmination of ten days long festival called Ganeshotsav, one of the most important festival celebrated in Westerm region of India.This festival is celebrated with greater pleasure and happiness but it has a negative side of creating water pollution(1,2). As a part of final ritual of Ganesh Chaturti Celebration, the clay Idols of Lord Ganesh along with floral offerings, leaves, coconuts, etc are immersed in various water bodies resulting in alarming increase in pollution level in the water bodies thereby endangering the aquatic flora and fauna $(3,6)$. Organic matters like plant remains materials, dead plants, grass, leaves, sewage, manure or even food waste is present in the water body and they are decomposed by 
microorganism such as bacteria.The aerobic bacteria breakdown the organic matter and for their decomposition bacteria utilizes the dissolved oxygen from the water.Oxygen concentration used by microorganism to break the chemical compounds is called as Biochemical Oxygen Demand(BOD) .If there is high amount of organic matter to be decomposed then there will be large number of microorganism. This microorganism then take greater amount of oxygen. Therefore BOD level will be high. When the organic waste is dispersed or consumed through the water, BOD level will begin to decrease.BOD test also estimate the level of different ions like ferrous and sulphide ion. Reduced form of nitrogen can be oxidized by BOD unless their oxidation is prevented by inhibitor (4).

\section{Methodology:}

Biological Oxygen Demand (BOD) is determined by iodometric titration using Wrinkler $\mathrm{A}$ and Wrinkler B. This determination is carried out immediately after collection of water samples from the lake and after 5 days kept in incubator at 19.50 $\mathrm{C}$ temperature. Difference between the two gives the value of Biochemical Oxygen Demand.

For DO1 : To the Water sample, Wrinkler's Reagent A and Wrinkler's Reagent B were added.This result in formation of precipitate, which is allowed to settle. After settlement the precipitate is dissolved in acid titrated against Sodium thiosulphate, which was standardized against $\mathrm{K} 2 \mathrm{Cr} 2 \mathrm{O} 7$.

For DO5: $250 \mathrm{ml}$ of water sample was directly collected from the lake in a BOD bottle, taking care that no air bubbles get collected. It was immediately wrapped with black paper and kept in an Incubator (200C )for 5 days. After 5 days of incubation, $2.0 \mathrm{ml}$ Wrinkler's Reagent A and $2.0 \mathrm{ml}$ Wrinkler's Reagent B were added to the water sample.The precipitate formed was allowed to settle.The precipitate was then dissolved in $\mathrm{H} 2 \mathrm{SO} 4$.The solution obtained thereby was titrated against $0.025 \mathrm{~N}$ Na2S2O3 using starch as Indicator.

The following equation used to calculate Dissolved Oxygen (DO5) (4).

$1000 \mathrm{ml}$ of $1 \mathrm{~N} \mathrm{Na} 2 \mathrm{~S} 2 \mathrm{O} 3=8 \mathrm{gm} \mathrm{O} 2$
3. Result and Discussion:

Biochemical Oxygen Demand:

Table 1: Amount of Dissolved Oxygen (DO1)

\begin{tabular}{|c|c|c|c|}
\hline \multirow{2}{*}{ Periods } & \multicolumn{3}{|c|}{ Dissolved Oxygen(DO ${ }_{1}$ ) in } \\
& \multicolumn{3}{|c|}{ ppm } \\
& S1 & S2 & S3 \\
\cline { 2 - 4 } & & 2.242 & 2.242 \\
Before & 2.242 & \pm 0.000 & \pm 0.000 \\
Immersion & $\pm 7.071 \times 10^{-4}$ & & 1.798 \\
\hline During & 1.816 & 1.829 & \pm 0.0103 \\
Immersion & \pm 0.01077 & \pm 0.01343 & \\
\hline Post & 1.067 & 1.067 & 1.067 \\
Immersion & \pm 0.000 & $\pm 7.071 \times 10^{-}$ & \pm 0.000 \\
& & 4 & \\
\hline
\end{tabular}

Table 2: Amount of Dissolved Oxygen $\left(\mathrm{DO}_{5}\right)$

\begin{tabular}{|c|c|c|c|}
\hline \multirow[t]{2}{*}{ Periods } & \multicolumn{3}{|c|}{$\begin{array}{c}\text { Dissolved Oxygen }\left(\mathrm{DO}_{5}\right) \text { in } \\
\text { ppm }\end{array}$} \\
\hline & S1 & S2 & S3 \\
\hline Before & 2.167 & 2.167 & 2.167 \\
\hline Immersion & \pm 0.000 & \pm 0.000 & \pm 0.000 \\
\hline During & 1.579 & 1.551 & 1.608 \\
\hline Immersion & \pm 0.0494 & \pm 0.0488 & \pm 0.000 \\
\hline Post & 0.000 & 0.000 & 0.000 \\
\hline Immersion & \pm 0.000 & \pm 0.000 & \pm 0.000 \\
\hline
\end{tabular}

The following equation was used to calculate Biological Oxygen Demand (BOD)

$\mathrm{BOD}=\mathrm{DO}_{1}-\mathrm{DO}_{5}$ 
Table 3: Amount of BOD

\begin{tabular}{|c|c|c|c|}
\hline \multirow{2}{*}{ Periods } & \multicolumn{3}{|c|}{ BOD in ppm } \\
\cline { 2 - 4 } & $\mathrm{S} 1$ & $\mathrm{~S} 2$ & $\mathrm{~S} 3$ \\
\hline Before Immersion & 0.075 & 0.075 & 0.075 \\
\hline During Immersion & 0.237 & 0.278 & 0.19 \\
\hline Post Immersion & 1.067 & 1.067 & 1.067 \\
\hline
\end{tabular}

Table 4: Amount of BOD

\begin{tabular}{|c|c|c|c|c|c|}
\hline \multirow{2}{*}{ Periods } & \multicolumn{3}{|c|}{ Total BOD $\mu \mathrm{g} / \mathrm{ml}$} & \multirow[b]{2}{*}{$\begin{array}{c}\text { W } \\
\mathrm{H} \\
\mathrm{O} \\
\mu \mathrm{g} / \\
\mathrm{ml}\end{array}$} & \multirow{2}{*}{$\begin{array}{c}\text { USP } \\
\mathrm{H} \\
\mu \mathrm{g} / \mathrm{ml}\end{array}$} \\
\hline & S1 & $\mathrm{S} 2$ & S3 & & \\
\hline $\begin{array}{c}\text { Before } \\
\text { Immersion }\end{array}$ & 0.075 & 0.075 & 0.075 & \multirow{3}{*}{6.0} & \multirow{3}{*}{5.0} \\
\hline $\begin{array}{c}\text { During } \\
\text { Immersion }\end{array}$ & 0.237 & 0.278 & 0.19 & & \\
\hline $\begin{array}{c}\text { Post } \\
\text { Immersion }\end{array}$ & 1.067 & 1.067 & 1.067 & & \\
\hline
\end{tabular}

\section{Level of BOD represented by graph:}

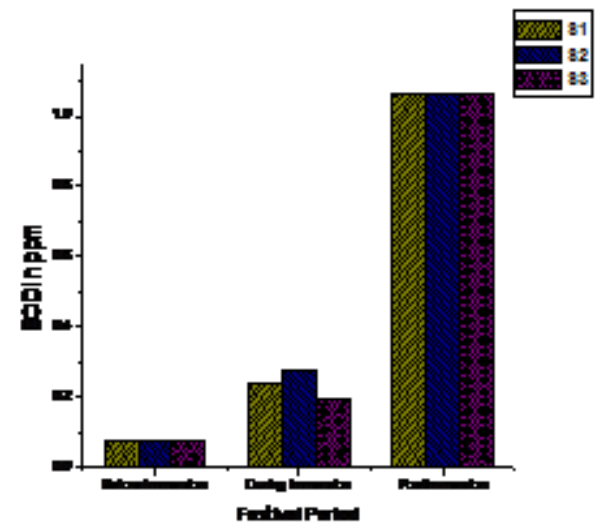

Figure 1: Graph of BOD in ppm Vs Festival

\section{Periods}

\section{Conclusion:}

BOD values varied significantly among the ponds and lakes. The highest value after immersion activity is $1.067 \mathrm{ppm}$ at all three stations of sample collection of lake water and the least value is 0.075 $\mathrm{mg} / \mathrm{l}$. All these values lie below the FEPA standard (Federal Environmental Protection Agency,Nigeria,1919) of $30 \mathrm{mg} / \mathrm{l}$. The permissible limits set by APHA (1992) is $4 \mathrm{mg} / \mathrm{l}$ whereas the permissible limits set by BIS is 3.0ppm.This is significantly different from the highest value of $1.067 \mathrm{mg} / \mathrm{l}$ obtained from this study. Accumulation of low BOD result in organism being stressed and suffocated (APHA, 1992)

\section{Reference:}

1) Ehiagbonare. J. E. and Ogunrinde.Y. O., (2010),Physico-chemical analysis of fish pond water in Okada and its environs, Nigeria,African Journal of Biotechnology,9(36), 5922-5928.

2) Kaur R. D. O,(2013), Comparison of immersion effects of idols made of different materials on the water quality parameters, Indian journal of Fundamental and applied life sciences,13(1),16-23.

3) Murthy.K.S. and B.R.Kiran, (2013), Review On Usage Of Medicinal Plants In Fish Diseases,International Journal Of Pharma And Bio Sciences, 4(3), 975 - 986.

4) Andrew D.E.,AWWA Chair,Lenore .S.Clesceri,WEF,EugeneW.Rice,APHA,Arnold E.Greenberg.Std methods for Examination of Water andwaste water, APHA,AWWA, Water Environment Federation ( 2005) ( ${ }^{21 \mathrm{st}} \mathrm{ed}$.).

5) Adefemi S.O,Awokunmi E.E,(2010),Determination of water parameters and heavy metalsin the water sample from Itaogbolu, J of Env.Sci \& Tech,4(3), 145-148.

6) Das K. K, Panigrahi T, Panda R.B, (2012), Idol Immersion Activities Cause Heavy Metal Contamination in River Budhabalanga, Balasore, Odisha, India, International Journal of Modern Engineering Research (IJMER), 2(6), 4540-4542. 